\author{
Jolanta STEC-RUSIECKA ${ }^{1}$ \\ Alicja SOBKOWIAK ${ }^{2}$
}

\title{
GOOD PRACTICES IN THE FIELD OF ECO- INNOVATION IN THE PODKARPACKIE PROVINCE
}

\begin{abstract}
The article refers to the concept of sustainable development and eco-innovation. Strengthening the regional economy and building their competitive advantage based on innovation and knowledge are the directions of contemporary development policy of the European Union, expressed in the "Europe 2020" strategy. One of the instruments for the implementation of sustainable development are eco-innovations. As a direct result of the implementation of eco-innovations is the fact that they bring some positive effects on the environment, and in relation to the organization - they bring tangible benefits (such as reducing the consumption of energy and raw materials, increasing resource efficiency, better and cheaper waste management, improving the image of the organization). In Poland, a large part of the economic structure is traditional material- and energy-intensive industrial sectors. Implementation of the modern environmental technologies is becoming a major challenge for the region. The authors of the article present examples of implementation of good eco-innovative solutions for enterprises operating in the Podkarpackie Province. The presented examples show that the implementation of eco-innovations significantly affect the competitiveness of the company and thus also the competitiveness of the region in which the companies operate. High competitive position could in fact be achieved through innovation, at the level of companies, regions and entire economies.
\end{abstract}

Keywords:Eco-innovation, regional development, green economy, sustainable development

\section{INTRODUCTION}

The article presents examples of eco-innovative solutions in the region, which can be an inspiration to businesses in the implementation of the concept of sustainable development. Shaping the innovation requires proper tools, the same statements are important but without practical solutions not so useful. In modern economies ranking of regions is steadily increasing. Nowadays regions are one of the most significant key policy leaders to stimulate eco-innovation in all areas of social and economic life.

\footnotetext{
${ }^{1}$ Mgr Jolanta Stec - Rusiecka, Katedra Przedsiębiorczości, Zarządzania i Ekoinnowacyjności, Wydział Zarządzania, al. Powstańców Warszawy 12, 35-959 Rzeszów, tel. +48 17865 1165, autor korespondencyjny: e-mail: rusiecka@prz.edu.pl

${ }^{2}$ Mgr Alicja Sobkowiak, Katedra Przedsiębiorczości, Zarządzania i Ekoinnowacyjności, Wydział Zarządzania, al. Powstańców Warszawy 12, 35-959 Rzeszów, tel. +48 17865 1165, e-mail: alicja_s@prz.edu.pl
} 


\section{ECO-INNOVATION AND SUSTAINABLE DEVELOPMENT}

The main driving force of eco-innovation is sustainable development. Eco-innovation, like all innovations can be divided into four basic groups: product, process (technical technological), organisational (in management) and marketing.

According to M. Carley and P. Spapens eco-innovations are the conducted intentionally what is characterized by the enterprise, including the stage of product design and integrated management during its life cycle, which contributes to the ecological modernization of the industrial societies by taking into account the environmental problems in the development of products and related processes. Eco-innovations lead to integrated solutions to reduce capital and energy resources, and at the same time increasing the quality of product or service ${ }^{3}$.

Eco-innovations allow to overcome the barriers that exist in the functioning of the company, which stimulates the growth of their competitiveness and contributes to improving the situation in the entire region.

An example of eco-innovation and the basis for the creation of eco-innovation may be the idea of "clean" or "cleaner" production and more conducive to the concept of the product life cycle "from cradle to cradle ". Thinking in terms of the product, life cycle from "cradle to cradle", what is the assumption at the design stage, that even the total use and consumption of the product does not mean the creation of waste, but only the raw material which can be useful in further cycles of production . In eco-innovative economy there will be no place for waste understood so far, so it becomes unnecessary for the most of waste incinerators, dumps, etc. to operate. Such reasoning leads to the elimination of waste, especially toxic, at every stage of production or consumption. In doing so, we stop wasting or abusing resources, mainly energy.

The eco-innovation strategies may include the following:

- $\quad$ cleaner production, used to improve the eco-efficiency and reduce risks to humans and the environment;

- eco-efficiency, defined as the provision of competitive goods and services that satisfy human needs and improve the quality of life through progressive reduction of negative environmental impact and resource usage throughout the life cycle to a level that is at least consistent with the estimated natural ability to reconstruct resources;

- eco-design, the inclusion of environmental issues in all phases of product development, in order to produce goods with the least possible environmental impact at every stage of the life cycle;

industrial ecology, interpreted as the study of the flow of materials and nergy in the industrial and consumer activities, the impact of these processes on the environment and the impact of economic, political, legal and social flow, usage and transformation of resources;

\footnotetext{
${ }^{3}$ M. Carley, P. Spapens, Dzielenie się światem, Instytut na Rzecz Ekorozwoju, Białystok Warszawa 2000, p. 157.
} 
- $\quad$ industrial symbiosis as engaging traditionally separate industries in the process of joint development of a competitive advantage, using the physical exchange of materials, energy, water and by-products. The key of industrial symbiosis are collaboration and the synergistic possibilities offered by geographic proximity;

biomimicry, which uses nature as a source of inspiration and as a model, measure and inspiring the development of cleaner products, materials and processes, while imitating renewability and safety in use, such as in nature;

- green chemistry, defined as the design, development and implementation of the eco-innovative chemical products and processes to reduce or eliminate the use and production of hazardous substances ${ }^{4}$.

Eco-innovativeness is a thinking and acting leading to the creation of eco-innovation or eco-innovative relation to society and economic in micro businesses or entire economies at the macro level, but also individuals, involving the active proecological commitment to reconstruction of societies and economies. Eco-innovativeness is a specific way of thinking and ecological activities, an indication of the specific environmental attitudes, as well as clearly defined direction of commitment to innovation. Eco-innovativeness can also be a measure and image of involvement in proecological change of societies and economies, expressed qualitatively and quantitatively. Ecoinnovativeness is included in a classical understanding of the theory of innovation management, however, strictly specifies the achievement of ecological purpose. Ecoinnovativeness is also a model of vision for the future, as well as a part of the mission of societies, economies, businesses 5 .

The policy concerning the protection of the environment from excessive interference of entrepreneurs is called sustainable development policy. We can call it a green policy which being a political ideology, is a set of ideas, values and beliefs that underpin an active and open civil society, developing in accordance with the principle of sustainable development and respecting the rights of man and nature. This policy assumes that its core values are:

- decentralisation,

- community economy,

- $\quad$ respect for diversity,

- $\quad$ global responsibility,

- $\quad$ taking future into account ${ }^{6}$.

Eco-innovation understood as a process of placing on the market new products and processes in order to minimize the adverse impact on the natural environment of companies and society, as well as the process of rational management of natural resources

\footnotetext{
${ }^{4}$ L. Woźniak, B. Ziółkowski, A. Warmińska, S. Dziedzic, Przewodnik ekoinnowacji. Diagnoza trendów i dobre praktyki, Wyd. Politechniki Rzeszowskiej, Rzeszów 2008, p. 10 [in:] Berkel van R., Waste prevention through business innovation. Waste \& Recycle Conference. (Re)defining roles and responsibilities to achieve viable outcomes, http://www.c4cs.curtin.edu.ak/van Berkel (WR 2005).pdf.

${ }^{5}$ L. Woźniak, S. Dziedzic, M. Woźniak., K. Kud, Cele i zasady wdrażania ekoinnowacji

w zarządzaniu firma i rozwojem regionu, Rzeszów 2011, p. 25.

${ }^{6}$ Ibidem p. 61 .
} 
is expected to meet a number of objectives. These objectives can be described as a system of measures concerning:

- $\quad$ reduction of pollution and waste generated in the process of production and consumption of products,

- $\quad$ improvement of the quality of life, through the use of eco-innovative technologies that reduce the excessive consumption of resources, but also improve the quality of the benefits derived from them,

- $\quad$ market attractiveness and business benefits associated with the image of environmentally friendly companies and products,

- financial savings from the reduction of consumption of raw materials and energy, in accordance with the principle that pollution prevention is cheaper than those associated with the leveling of their effects,

- reduction of the risks associated with the management, storage and disposal of toxic waste at the place of production and beyond,

- $\quad$ effective use of limited development capital, which is at the disposal of the business,

- $\quad$ promotion of the new and integrated approaches to eco-innovation in processes and products,

- $\quad$ elimination of the barriers to the wider use of ecologically innovative solutions,

- $\quad$ creation of a larger market for ecological solutions,

- $\quad$ increasing the eco-investment capacity of SMEs ${ }^{7}$.

The need to create an economy based on knowledge and innovation is shown in the paper of the Ministry of Economy, which stated that existing sources of economic growth, such as relatively low labor costs, the availability of cheap raw materials, favorable geographic location or accession to the European Union will run out. Therefore it is necessary to look for new sources of competitive advantage. Development trends of developed countries show that only building a competitive dominance based on knowledge and innovation can ensure sustainable development in the short and medium term. The main determinant of well-functioning modern economy are innovations. Undoubtedly, they are the driving force behind today's developed economies. Constant search for new combinations of production factors, product innovation, manufacturing techniques, the organization of economic activities and sales results in successful companies, and thus on the overall of socio-economic development ${ }^{8}$.

Eco-innovations contribute to sustainable development. As a direct result of the implementation of eco-innovation is the fact that they bring some positive effects on the environment, and in relation to the organization - they bringing tangible benefits (such as reducing the consumption of energy and raw materials, increasing resource efficiency, better and cheaper waste management, improving the image of the organization).

W. Sokol lists the following barriers and stimulators of the development of ecoinnovation in Poland. For the stimulator he recognized the potential of small and mediumsized enterprises in Poland. Another stimulator is the prospects for the development of

\footnotetext{
${ }^{7}$ Ibidem pp. 69-70.

8 Ministerstwo Gospodarki, Departament Rozwoju Gospodarki, Kierunki zwiększania innowacyjności gospodarki na lata 2007-2013, Warszawa 2006, pp. 1-122.
} 
environmental technologies in both the EU and globally. Industries related to environmental protection are the rapidly growing part of the EU economy, especially air pollution control, waste water management, waste management, soil remediation, renewable energy and recycling. Among other stimulants significant technological needs of SMEs in Central Europe were listed. Along with these needs a number of requirements related to environmental technologies, which may cause technological development directly in harmony with the natural environment. It also indicated the system of financing environmental projects and regulatory requirements, economic instruments, including a system of environmental charges and fines, institutions, programs, international projects and networks of support, environmental management at the regional level, provided that the technology needs of SMEs included in the Environmental Protection Plans. To the barriers to of the development of eco-innovation W. Sokol scored incoherent and inconsistent terminology used in the documents relating to the issue. In relation to a significant proportion of the generated gross domestic product, it is also a significant participation of SMEs in pollution of the environment. An important barrier is the sphere of motivation and awareness of entrepreneurs. The research presented by the same author suggests that a small percentage of entrepreneurs see the legal obligation under the provisions of eco-innovation. The main motive of interest in eco-innovation is the desire to reduce costs and improve the company's image. Moreover, it is a natural motivation resulting from the current economic paradigm and if one expect changes in this respect, should seriously consider the change of the same paradigm. A significant barrier W. Sokol also sees a significant barrier in the awareness of SMEs in relation to contamination. It is estimated that the share of industrial pollution is about $70 \%$, while between $75 \%$ to $90 \%$ (of European SMEs believe their activities do not adversely affect the environment, therefore the do not take any action to reduce this impact ${ }^{9}$.

\section{EXAMPLES OF ECO-INNOVATION USED IN THE REGION AND THEIR IMPACT ON INCREASING THE COMPETITIVENESS OF PODKARPACKIE PROVINCE}

The Podkarpackie Province is located in south-eastern part of Poland and it covers approximately $18,000 \mathrm{sq}$. $\mathrm{km}$ which constitutes $5.7 \%$ of total area of Poland. The area is inhabited by $2,130,000$ persons $(5.5 \%$ of the country population). The southern and eastern border of the Podkarpackie Province is also a border of Poland with Ukraine and Slovak Republic. The region is known for its rich deposits of such natural resources as oil and natural gas as well as such mineral raw materials as sulphur, gypsum, sandstone and limestone being currently extracted in modern mines. The city of Rzeszow is the capital and the seat of local government of the region. The city is economic, academic and cultural centre of the Podkarpackie Province. The relief structure of the province is varied. The northern part of Podkarpackie consists of lowlands and uplands, while the Lower Beskid Mountains and the Bieszczady Mountains dominate the south. Forests take up onethird of the total area, with the most heavily forested areas occurring in the Bieszczady

\footnotetext{
${ }^{9}$ L. Woźniak, S. Dziedzic, M. Woźnaik, K. Kud, Cele i zasady ... op.cit. p. 105-107 [in:] W. A. Sokół, Bariery $i$ stymulatory wdrażania technologii środowiskowych w Polsce, Debata Ekoinnowacje made in Poland. Bliska czy odległa przyszłość, Poleko 2009, Poznań, 24 listopad 2009.
} 
Mountains and the Sandomierz Basin in the northern part of the Province. Almost half of Podkarpackie is set aside for agriculture, but fertile soil is found primarily in the middle portion of the region.

The structure of regional industry is dominated by sectors like: aviation, IT, agro-food, chemical and electrical engineering, generating a total of more than $70 \%$ production of the region. Empirical evidence indicates that there is a large number and variety of institutions supporting the development of the region, and the range of services provided by them is multidirectional.

Each region must find its own path of development, which will become the source of its competitive dominance. They should be local structures and mechanisms of development created and an effective system of local financial management and resources worked out ${ }^{10}$. The success of economic and civilization are related by these companies and regions which develop and unleash a capacity to generate innovation (knowledge, intellectual capital) ${ }^{11}$.

A measure of the overall economic situation of the region and country is generally assumed with gross domestic product (GDP) per capita. It expresses the best present situation in the formation of income, which are then consumed or converted into physical, human and public capital. In the long term, this revenue define the level of life, advancement of civilization and prospects for further development of the region. ${ }^{12}$

The value of regional GDP and the amount of income, attributable to the disposal of per capita situates Podkarpackie Province on one of the last places in the European Union, except for Bulgarian and Romanian regions.

The average level of GDP per capita calculated by Purchasing Power Standard (PPS) for the European Union in 2008 was 25,100 PPS. In the Podkarpackie Province GDP per capita was 9,700 PPS (39\% of the EU average) and, compared with year 2005 has increased by $21.3 \%$. This is higher than the EU average, although the position of the region has deteriorated during this period. There was a decrease from the position 259 to 263.

Between 2004 - 2010 there was a systematic decrease in regional GDP per capita compared to the national level from $70.0 \%$ in 2004 to $67,3 \%$ in 2010 (Poland $=100 \%$ ). It should be emphasized that this is a very disturbing phenomenon. For comparison, it is worth noting that the level of gross domestic product per one inhabitant in 2010, recorded in Podkarpackie Province was $41.4 \%$ lower from the level achieved by the Mazowieckie Province.

Podkarpackie Province is characterized by a clear internal differentiation in terms of GDP per capita. In subregions of Rzeszow and Tarnobrzeg average GDP per capita in 2010 amounted respectively 29668 and 26316 PLN while in the subregions of Krosno and Przemysl it was 21602 and 19718 PLN. It is worth noting that regional differences in this matter since 2004 appears to be growing. ${ }^{13}$ In 2007-2010, the annual average value of the inflow of foreign direct investment (FDI) to the region of Podkarpackie reached 209

\footnotetext{
${ }^{10}$ Raport o innowacyjności województwa podkarpackiego w 2007 roku, T. Baczko (eds.), Warszawa 2008 , p. 5

${ }^{11}$ Innowacje w strategii rozwoju organizacji w Unii Europejskiej, S. Janusz (eds.), Difin, Warszawa 2009, p. 11.

${ }^{12}$ Raport o innowacyjności województwa podkarpackiego w 2007 roku, T. Baczko... op.cit. p. 19.

${ }^{13} \mathrm{http}: / /$ monitoruj.podkarpackie.pl/gospodarka-regionu, accessed 20.07.2013.
} 
million EURO (11th place in the country). The largest value of foreign capital in the Podkarpackie companies came from Germany (498.9 million in 2011). The second in this respect, investment partner in Podkarpackie is France, where the amount of capital in 2011 was 422.4 million PLN. The next, largest foreign investor in 2011, were companies from Luxembourg (230.7 million PLN), Cyprus (210.5 million PLN), the Netherlands and Belgium (174.3 million PLN), Britain (31.6 million PLN) and Spain (22.4 million PLN). In the years 2003-2009 the value of U.S. investments decreased from 226.2 million PLN in 2003 to 63 million PLN in $2009^{14}$.

A. Klasik pointed to three main sources of competitiveness in the region, which include: physical and institutional infrastructure, and intellectual potential located in the region. ${ }^{15}$

Analysis of ways to define the competitiveness of the regions indicate essentially two trends in the discussion of this category. Therefore it can be considered as the region's competitiveness as a result of interaction of potentials generated at the individual operation fields of the region, namely: economic, social, cultural, innovative, technicalcommunication, etc ${ }^{16}$.

The potential of competitiveness of the region is a kind of indicator of the ability of the region's development and well-being of its inhabitants, and a catalyst for attracting external investment and human capital.

Competitiveness of regions can be also considered as an assembly of competitive dominance, and therefore as the potential to compete with other regions for the capital conditioning the development of the individual and the welfare of its people. Competitiveness is understood as the result of the strengths of the area that allows for a competition in a particular area and to compete against other regions ${ }^{17}$.

The regional competitive position is the place where the region takes in the ranking list. The position is largely determined by networks, regional arrangements, institutional arrangements, as well as statistical relations, as the unemployment rate, the financial situation of the region, the amount of debt and other ${ }^{18}$.

Competitive ability is the ability to face the challenges of the environment. It is defined as: economic culture, which can create favorable conditions for business development, implementation of innovative and eco-innovative solutions and the inflow of investors. Currently, more often for the creation of the competitive ability of the region intangible factors are responsible, so widely understood human capital, innovations,

\footnotetext{
${ }^{14} \mathrm{http} / / /$ monitoruj.podkarpackie.pl/gospodarka-regionu, accessed 20.07.2013.

${ }^{15}$ A. Klasik, Konkurencyjność województwa śląskiego na tle innych regionów. Ujęcie syntetyczne [in:] Województwo śląskie. Integracja, konkurencyjność, nowe inicjatywy. II Śląskie Forum Rozwoju Lokalnego i Regionalnego, Katowice 2001, pp. 99-100.

${ }^{16} \mathrm{~K}$. Falkowski, Czynniki i ograniczenia konkurencyjnego rozwoju regionów przygranicznych Ujęcie teoretyczne [in:] Wschodnie pogranicze rozszerzonej Unii Europejskiej, Czynniki konkurencyjności, E. Teichmann (eds.), Warszawa 2006, p. 19.

${ }^{17}$ A. Klasik, Przedsiębiorczość i konkurencyjność a rozwój regionalny, Katowice 2006, p. 48.

18 J.W. Bossak, Konkurencyjność gospodarki Polski a proces integracji europejskiej i rozwoju gospodarki opartej na wiedzy [in:] Konkurencyjność Polski w procesie pogtębiania integracji europejskiej i budowy gospodarki opartej na wiedzy, T. Michalski, K. Piech (eds.), Warszawa 2008, p. 545.
} 
flexibility of economic structures, knowledge resources, skills and competencies, networks and management systems. ${ }^{19}$

The competitiveness of the region can also indicate:

- the quality of human capital measured by the age structure of the population and the level of education,

- $\quad$ percentage of companies implementing innovative solutions

- increasing investment in research.

The quality of human capital in the Podkarpacie region is not significantly different from the average for the Polish state. The population of Podkarpacie is statistically slightly younger than the national average. Typical of the Podkarpacie region is relatively high proportion of people in working age. It can be concluded, that the level of education in Podkarpackie does not differ polish average, which means that the potential for creating a knowledge society, because of the quality of human capital in the region, is similar to in Poland.

Podkarpackie Province is highly ranked in terms of percentage of companies conducting innovation actives in total number of industrial companies. On this basis, it is possible to conclude that entrepreneurs operating in Podkarpacie region have more than the average propensity to innovate, which should improve the ability of regional economy to compete. A weakness of Podkarpackie Province is low level of expenditure on research and development. A possible reason for this is small ability to compete for funds by research institutions in Podkarpackie Province and entire Eastern Poland.

It can be concluded that the Podkarpackie region strengths include:

- demographic potential (high percentage of people of working age and pre-working age),

- the level of education of the population,

- $\quad$ rich but poorly used environmental resources that should be a factor in accelerating the development of different forms of tourism,

- $\quad$ border location, which currently has a small economic importance, but in the future it should be more important development factor.

Podkarpackie Province is one of the regions with rich natural beauty, because about $48 \%$ of total area is covered with different forms of protection (higher proportion have only Świętokrzyskie - 62\% and Małopolskie - 58\%). On the territory of Podkarpackie two national parks are located - The Bieszczadzki National Park with an area of 29000 ha and Magurski National Park - with an area of 19000 ha. In terms of surface area covered under the National Parks province, Podkarpackie ranks second in the country (after the Podlaskie Province).

Eco-innovations for themselves create a demand by appearance of a new need or desire to satisfy the existing one in new, different way. Eco-innovations are the driving force of economic growth and they contribute to raising the level and quality of social life, and therefore they have a significant contribution to eliminating social inequalities. The increase of the competitiveness of the region follows by an increase in the production of goods and services, through effective use of property and personal factors of production. Increasing the quantity and improving the quality of our goods and services are the basis

\footnotetext{
${ }^{19}$ J. W. Bossak, W. Bieńkowski, Międzynarodowa zdolność konkurencyjna kraju i przedsiębiorstw, wyzwania dla Polski na progu XXI wieku, Warszawa 2004, p. 37.
} 
of changes in a process, in the level and quality of life of the inhabitants of the region. However, the competitiveness of the economy lies in the capacity for rapid introduction of modern technical and technological solutions, organizational and management skills. Competitiveness based on properly stimulated and targeted growth of innovation contributes to the development and sustainable growth of workplaces in the emerging and developing companies and in their cooperative and service environment. Growth of employment means improving the financial situation of the inhabitants of the region and equalization of the differences in the overall quality of life.

Efficiency of the regional economy undoubtedly affects its competitiveness because it shapes the structure of employment, affects the educational system (forcing adaptation to the needs of the market), and demographic issues of the region (including the level of migration). One of the indicators of economic efficiency is the amount of investment. Although on the basis of this indicator you can specify changes in terms of the performance of the region's economy, however, be aware that it also depends on other factors, not always amenable to quantitative research, and even the management of capital expenditures ${ }^{20}$.

In the context of an analysis of expenses on investment in different sectors of the regional economy shift from public to private sector can be observed, which refers to the development of private entities, as well as increase of activity and the level of entrepreneurial individuals. Capital expenditures in the private sector have more than doubled. As compared to 1999 it was an increase of 130\%, while investment in the public sector were $1 / 4$ of investment in the region ${ }^{21}$.

Another factor of the competitiveness of the Region - human capital - is a broad category and covers the demographic characteristics of a particular population (e.g. residents of the region) as well as the skills and competencies and intellectual potential of the group. Hence, human capital measurement indicators may include, among others: the age structure of the population, occupational structure, matching education to labor market needs, but also the number of operators registered in the region, education, number of universities, the number of students, professional activity of the inhabitants of the region, etc. R. Domanski defines social capital as the accumulation of knowledge, skills, health and vital energy in the particular community, but this factor requires constant mobilization and support. Intellectual potential and level of knowledge are important development factors of Podkarpackie Province which determine the structure and quality of the region's economy. Despite the growing number of students and the development of higher education, the Region is still on one of the last places (in 2008, only worse presented the Lubuskie Province). Similarly, in terms of academic staff, which number over the decade has nearly doubled, it still puts the Region in 12th place (2008). Apart from 16 higher education institutions in the region, there are colleges whose superior is the provincial government ${ }^{22}$.

20 A. Kołomycew, Wybrane aspekty konkurencyjności województwa podkarpackiego, Studia i Materiały. Miscellanea Oeconomicae, Rok 14, Nr 1/2010, Wydział Zarządzania i Administracji Uniwersytetu Humanistyczno - Przyrodniczego Jana Kochanowskiego w Kielcach, Przedsiębiorczość a rozwój regionalny p. 207.

${ }^{21}$ Ibidem p. 208.

${ }^{22}$ Ibidem p. 208. 
Logical, resulting in a well-understood vision and mission, the way to develop countries, regions and companies are still rare. Eco-innovative thinking is not yet common in organizations. The real development of eco-innovation begins when they become the primary objective of seeking innovative solutions, aimed at the pro-social and ecological development. Such actions, directed at introducing innovative solutions which meet the criteria of eco-innovation, also appeared in some of the local companies:

1. Meat Plant SMAK-Górno LLC processed meat and produces cold cuts. In a very interesting way the company approach to the environmental protection issue. Many elements of the fundamental processes creates a coherent, logical sequence of solutions designed to reduce or eliminate the negative impact on the environment. The use of ecoinnovative food processes and products is also a return to the best natural and traditional solutions which are very important in the food industry. Eco-innovation can be called a production of regional and traditional products which, after years of absence and disappearance come back into the production process, they are revived, and at the same time clearly intended to protect the health and characterized by top quality. The SMAKGórno company started the project ZERO E, which is concerned with the manufacture of products completely free of any synthetic chemicals - preservatives, colorants, antioxidants, emulsifiers, thickeners, water binders etc. The end result of such thinking (fully bearing the signs of eco-innovation) are natural products. At SMAK-Górno many elements of the technological line, as well as infrastructure of waste management have eco-innovative character. Stove for the incineration of waste, willow growing in the plots intended to the use of organic waste, logically coupled acquisition and heat recovery system, eco-innovative raw material sourcing model and marketing, are other examples of forward-looking solutions far ahead of the standards characterized by this sector ${ }^{23}$.

2. Meat Plant Jasiołka specializes in traditional local ecological sausages which are made without preservatives and other synthetic chemicals. All sausages produced by the company are prepared according to the 150 years olds recipes. Up to 5 products from Jasiołka are registered as Podkarpackie traditional products. The company has ecological Certificate - ECO WARRANTY. It is also a member of the Polish Chamber of Local and Regional Product and the Association of Polish Ecology ${ }^{24}$.

3. Aggregate Manufacturing Company and Geological Services KRUSZGEO JSC in Rzeszow as the first in Podkarpackie has been certified, which is a confirmation of the implementation in the company the certificate called EMAS - the European EcoManagement and Audit Scheme. In March 2011, the company has passed the stage of accredited verification, and in July 2011 it was entered to the national register of EMAS. By getting certified, the company entered the European elite. The Eco-Management and Audit Scheme is implemented in a fully voluntary environmental management system, which confirms the continuous improvement of environmental performance in organization. Organizations which have implemented EMAS share on their websites up to date, validated environmental statements for the last year. The offer of the company includes: geological and drilling work, the development of documentation in the field of hydrogeology, engineering geology and raw materials, production and conversion of building and mineral materials - natural and broken, the production of concrete and

\footnotetext{
${ }^{23}$ S. Dziedzic, L. Woźniak, Ekoinnowacje jako priorytetowy kierunek „Regionalnej Strategii Innowacji Województwa Podkarpackiego”, Rzeszów 2013, pp. 49-51.

${ }^{24}$ Ibidem p. 51
} 
mortars. This system is based on continuous improvement of environmental performance, providing information on environmental performance, conducting an open dialogue with stakeholders, and actively involving employees in the process of environmental management. Implemented EMAS system in the company is a confirmation of the fact that it meets the legal provisions on the protection of the environment, as well as makes effort to ensure that after extracting the aggregate the appropriate rehabilitation of the land will be carry out, leaving the inhabitants of the surrounding area fit for use. The company seeking for registration should organize waste management in their areas, to adapt its own documentation to the relevant requirements, resulting from the essence of EMAS, and then subjected to appropriate verification. The transition of the positive verification makes it possible to request the organization strives to be entered in the register of the Regional Directorate of the Environment. This company is an example of successful implementation of organizational eco-innovation, which makes it the leader in this field in Podkarpackie Province ${ }^{25}$.

4. Nowy Styl Group is one of the rapidly growing factory in the furniture industry. The company is listening to the expectations of the environment, create hundreds of new products, but do not forget about the responsibility for the environment in which they operate. For many years the company is trying to drive environmental policy. They implement the program called Eco-logically in three areas: people, product and environment. From 2012 the company belongs to the Coalition for Responsible Business. The primary goal of the Nowy Styl Group is to satisfy their customers. To provide customers with satisfactory products, they pay attention to the safety and quality of products. Before the company release the product, it is tested in an internal research unit. The safety of most products is confirmed by independent institutions. Clients provides instructions on how to install and use bought items what ensure the proper and correct use of their products. With the development of the company, Nowy Styl Group strives to full environmental responsibility for the supply chain and extend the life cycle of its products. Nowy Styl Group was founded in 1992 in Podkarpackie Province and it owes its development. The company feels responsible for the social and natural environment of the region. With the launch of the line Sedia Nature, the company has engaged in efforts to protect the Magurski National Park - one of the youngest and most beautiful in Poland. 5 zł income of each product line Sedia Nature supports the Magurski National Park in efforts to protect endangered species. The Group is also engaged in the promotion of Magurski National Park, because it encourages tourists to come to Magura and find the gems hidden in the Podkarpackie Province. Nowy Styl brand products are made with environmentally friendly materials and - where possible - the several times processed raw materials, which is why almost $100 \%$ of products can be recycled. The policy of the company is AUD - Avoid. Use. Dispose - avoid toxic materials, use reusable items and dispose of materials that can be recycled. Nowy Styl Group, developing its business, is aware of the influence they have on the environment. Operating in full compliance with applicable laws and implementing environmentally friendly solutions they continuously making efforts to minimize the negative impact on the environment. The growing awareness of the environment inspired the company to undertake new pro-environment and pro-social initiatives. The factories of the Group operates released gas purification system, which products initially saturated with chemicals, are in $99 \%$ cleansed. A similar

${ }^{25}$ Ibidem pp. 49-51. 
process occurs at a effluence treatment - effluences go in-depth filtration, and only then get into the groundwater. The manufacturing process used in the Nowy Styl Group, does not use toxic substances such as halocarbons, which are often used by other manufacturers for the production of polyurethane foams. What's more, the company does not use harmful substances such as cadmium, mercury, lead and arsenic. Stations of painting and gluing wood, were confirmed E1 standards for low formaldehyde emissions. A system of environmental management according to ISO 14001 in all factories of Nowy Styl Group was implemented. The company manufactures thermal energy by means of a waste and wood dust from its own production of wooden elements. Plastic waste processed in special substance, from which plastic parts for chairs are made. Thus recycling circle is closed within one factory. Since 2008, the company carried out a program of environmental education for employees of Nowy Styl Group. Attitudes of staff - and the people they are facing-can significantly affect the promotion of environmental awareness. "Be ECO-logic" is a program encouraging the behavioral change in their daily office work, from saving water and energy, to the conscious use of paper. The action aims at forming conscious, environmentally friendly attitudes of employees and promoting environmental awareness among business partners, associates, and even family members. Nowy Styl Group activities in the implementation of eco-innovative products and processes, place the corporation at the forefront of Carpathian companies. Nowy Styl Group actions are the example of a systematic approach to implementation, with full conviction of eco-innovative solutions. The successes of the Group are also proved by the fact that a well-understood and implemented environmental measures also provide an excellent economic results ${ }^{26}$.

5. Many-oriented environmental management systems can be found at WSK "PZLRzeszów" SA. It should be added that the management of the company refers to its involvement in the construction of the new generation of engines, whose essential feature is a large reduction of emissions of nitrogen oxides, which stems from the need to protect the earth's atmosphere. In this way the company can outstrip many competitors.

One of the signs of ecologically innovative thinking of the Management Board is to build, on the area of Communication Equipment Factory "PZL-Rzeszow", green office building, which will be completed in 2014. The building will have a LEED certificate (Leadership in Energy and Environmental Design). This environmental certification, which is determined by such criteria as: the location of the building, energy optimization, efficient use of water, the right materials, indoor environmental quality and innovative design. The building will become the headquarter of The Aircraft Propulsion Research and Development Center. The construction is related to a number of other procedures that must be followed. For example - At least $80 \%$ of construction waste should be recycled. Asphalt will be replaced by a clear concrete or paving stones, many of the materials will come from recycling and at least $20 \%$ of the building materials will be produced, extracted or recovered at a distance of not more than $800 \mathrm{~km}$ from the place of construction $^{27}$.

Presented examples show that the implementation of eco-innovations significantly affect the competitiveness of the company and thus also the competitiveness of the region in which the companies operate. The activity of eco-innovation consists all scientific,

\footnotetext{
${ }^{26}$ Ibidem pp. 51-54.

${ }^{27}$ Ibidem pp. 51-54.
} 
technical, organizational, financial and commercial activities that lead to the implementation of innovations. Some of these activities have an innovative character, while others do not, but they are necessary for innovation. Innovation activities also include research and development (R\&D), which is not always directly related to the creation of a specific innovation, but incurred expenses significantly affect the innovation and competitiveness of the region.

In terms of the internal expenditure actually incurred on R\&D based on the economic operator, Podkarpackie region occupied the 3rd place in 2010 in Poland and it was about 8 positions better in relation to the previous year. Even more preferably the Podkarpackie is presented in terms of investment in R\&D actually incurred for the economic operator. In this respect, Podkarpackie Province achieved the first place in 2010, which is about 9 positions better than year ago. In a significant extent, this position should be owed to the industry sector, which in terms of internal expenditure actually incurred, achieved in 2010 first position in the country. However, in the case of internal expenditure actually incurred outside the industry, Podkarpackie Province took the high 3rd place in the country in 2010. This is particularly important, because so far, not industrial sectors of the economy, especially services, are characterized by one of the lowest relative internal expenditure on $\mathrm{R} \& \mathrm{D}^{28}$

Increase of the competitiveness of the region is dependent on the investment. In 2012, capital expenditures established by companies in Podkarpackie Province, have increased compared to the previous year (after two years of decline). Capital expenditures for new facilities and improving existing property, incurred in 2012 by the surveyed companies, reached the value of 2967.0 million PLN and were (in current prices) higher than in the previous year by $11.7 \%$ (in Poland there was a decrease of $0.1 \%$ ). The largest increase over the previous year was recorded in expenditure on machinery, equipment and tools (for about 16.3\%), and slightly lower for buildings and structures (for 9.0\%). The value of investment purchases totaled 1881.8 million PLN and in comparison with the previous year increased by $13.2 \%$. The share of these products in total expenditure increased annually by $0.8 \%$. The year 2012 started with 1641 investments of a total estimated value of 1206.4 million $\mathrm{PLN}^{29}$.

There is a clear correlation between the presented phenomena and growth of ecoinnovation, which improves the functioning of the economy in the long run, strengthening and positively influencing its competitiveness.

\section{CONCLUSION}

Eco-innovations are mostly uniqueness and aims to encourage customers and partners for cooperation. However, eco-innovations are not present, without good practices that are the foundation of any business. Good practices are related to benchmarking, and so the process of comparing the effectiveness of the company from the competition. By measuring the effectiveness of the company and its individual processes, the information how the company prospers, how it presents itself against the competition and which

\footnotetext{
${ }^{28} \mathrm{http} / / /$ www.rsi.podkarpackie.pl/Strony/Nak\%C5\%82ady-wewn\%C4\%99trzne-inwestycyjnefaktycznie-poniesione-na-B-R-na-podmiot-gospodarczy. aspx?type=dlgFrame, accessed 30.08.2013. ${ }^{29}$ Raport o sytuacji społeczno-gospodarczej województwa podkarpackiego w 2012 r., Rzeszów 2013: 77-79.
} 
internal processes should be improve is obtained. Implementation of the modern environmental technologies is becoming a major challenge for the region. The green economy is considered in many ways including a number of issues, such as the development of clean technologies, renewable energy, energy efficiency and material change in patterns of consumption and production in a more sustainable way.

\section{BIBLIOGRAPHY:}

[1] Bossak J.W., Bieńkowski W., Międzynarodowa zdolność konkurencyjna kraju i przedsiębiorstw, wyzwania dla Polski na progu XXI wieku, Warszawa 2004.

[2] Bossak J.W., Konkurencyjność gospodarki Polski a proces integracji europejskiej i rozwoju gospodarki opartej na wiedzy [in:] Konkurencyjność Polski w procesie pogtębiania integracji europejskiej ibudowy gospodarki opartej na wiedzy, T. Michalski, K. Piech (eds.), Warszawa 2008.

[3] Carley M. Spapens P., Dzielenie się światem, Instytut na Rzecz Ekorozwoju, Białystok - Warszawa 2000.

[4] Dziedzic S., Woźniak L., Ekoinnowacje jako priorytetowy kierunek „,Regionalnej Strategii Innowacji Województwa Podkarpackiego”, Rzeszów 2013.

[5] Falkowski K., Czynniki i ograniczenia konkurencyjnego rozwoju regionów przygranicznych. Ujęcie teoretyczne [in:] Wschodnie pogranicze rozszerzonej Unii Europejskiej, Czynniki konkurencyjności, E. Teichmann (eds.), Warszawa 2006.

[6] http://monitoruj.podkarpackie.pl/gospodarka-regionu/, accessed 20.07.2013.

[7] http://www.rsi.podkarpackie.pl/Strony/Nak\%C5\%82ady-wewn\%C4\%99trzneinwestycyjne-faktycznie-poniesione-na-B-R-na-podmiotgospodarczy.aspx?type $=$ dlgFrame, accessed 30.08.2013

[8] Innowacje w strategii rozwoju organizacji w Unii Europejskiej, (eds.) S. Janusz, Difin, Warszawa 2009.

[9] Klasik A., Konkurencyjność województwa śląskiego na tle innych regionów. Ujęcie syntetyczne [in:] Województwo ślaskie. Integracja, konkurencyjność, nowe inicjatywy. II Śląskie Forum Rozwoju Lokalnego i Regionalnego, Katowice 2001.

[10]Klasik A., Przedsiębiorczość i konkurencyjność a rozwój regionalny, Katowice 2006.

[11]Kołomycew A., Wybrane aspekty konkurencyjności województwa podkarpackiego, Studia i Materiały. Miscellanea Oeconomicae, Rok 14, Nr 1/2010, Wydział Zarządzania i Administracji Uniwersytetu Humanistyczno Przyrodniczego Jana Kochanowskiego w Kielcach, Przedsiębiorczość a rozwój regionalny.

[12]Ministerstwo Gospodarki, Departament Rozwoju Gospodarki, Kierunki zwiększania innowacyjności gospodarki na lata 2007-2013, Warszawa 2006.

[13]Raport o innowacyjności województwa podkarpackiego w 2007 roku, (eds.) T. Baczko, Warszawa 2008.

[14]Raport o sytuacji społeczno-gospodarczej województwa podkarpackiego w 2012 r., Urząd Statystyczny w Rzeszowie 2013. 
[15]Woźniak L., Dziedzic S., Woźnaik M., Kud K., Cele i zasady wdrażania ekoinnowacji w zarzadzaniu firma i rozwojem regionu, Rzeszów 2011.

[16]Woźniak L., Ziółkowski B., Warmińska A., Dziedzic S., Przewodnik ekoinnowacji. Diagnoza trendów idobre praktyki, Wyd. Politechniki Rzeszowskiej, Rzeszów 2008.

\section{DOBRE PRAKTYKI W ZAKRESIE EKOINNOWACJI W WOJEWÓDZTWIE PODKARPACKIM}

Zaprezentowany artykuł odnosi sie do koncepcji zrównoważonego rozwoju i ekoinnowacji. Wzmocnienie gospodarki regionalnej i budowanie przewagi konkurencyjnej opartej na innowacjach i wiedzy są głównymi kierunkami współczesnej polityki Unii Europejskiej, wyrażonymi w strategii "Europa 2020". Jednym $\mathrm{z}$ podstawowych instrumentów, które służą skutecznej realizacji koncepcji zrównoważonego rozwoju są ekoinnowacje. Wynikiem wdrożenia ekoinnowacji jest przynoszenie pozytywnych skutków dla środowiska naturalnego. Ekoinnowacje przynoszą również wymierne korzyści dla organizacji, które je wdrażają (między innymi poprzez: zmniejszenie zużycia energii i surowców, zwiększenie efektywności wykorzystania zasobów, lepsze i tańsze zarządzanie odpadami oraz poprawę wizerunku firmy). Znaczna część polskiej gospodarki jest tradycyjna, dominują materiało- $i$ energochłonne sektory przemysłowe. $Z$ tych względów poważnym wyzwaniem dla regionu staje się wdrażanie nowoczesnych technologii ochrony środowiska. Autorzy przedstawiają w artykule przykłady „dobrych praktyk” wdrażania ekoinnowacyjnych rozwiązań w przedsiębiorstwach działających na terenie województwa podkarpackiego. Przedstawione przykłady są dowodem na to, że wdrażanie innowacji ekologicznych znacząco wpływa na konkurencyjność firm, a tym samym zwiększa konkurencyjność całego regionu, w którym działają przedsiębiorstwa. Innowacje wdrażane na poziomie przedsiębiorstw, regionów i całych gospodarek w rzeczywistości mogą przyczyniać się do wzmacniania ich wysokiej pozycji konkurencyjnej.

Slowa kluczowe: ekoinnowacje, rozwój regionalny, „zielona ekonomia”, rozwój zrównoważony

DOI:10.7862/rz.2013.hss.53

Tekst złożono w redakcji: wrzesień 2013.

Przyjęto do druku: styczeń 2014. 